\title{
Chemical, Rheological, Microbiological and Organoleptic Properties of Labneh Manufactured by Using Some Vegetable Oils
}

\author{
Mohamed Nour-Eldin Farid Hamad (Corresponding Author) \\ Dairy Department, Faculty of Agriculture, Damietta University, Egypt \\ Email: dr_mnour@du.edu.eg
}

\author{
Dina Hamed Amin El-Bushuty \\ Home Economics Department, Faculty of Specific Education, Damietta University, Egypt
}

\author{
Amaal Moatamed Hassan Abdallah \\ Dairy Department, Faculty of Agriculture, Damietta University, Egypt
}

\author{
Article History \\ Received: February 7, 2021 \\ Revised: March 11, 2021 \\ Accepted: March 21, 2021 \\ Published: March 23, 2021 \\ Copyright @ 2021 ARPG \& \\ Author \\ This work is licensed under \\ the Creative Commons \\ Attribution International \\ (c) (1) CC BY: Creative \\ Commons Attribution \\ License 4.0
}

\begin{abstract}
Vegetable oils have many nutritional and therapeutic benefits, as it contains essential fatty acids and antioxidant compounds. In this study, virgin olive oil, sunflower oil, corn oil, and sesame oil were used in labneh manufacture for increasing its health benefits. Labneh was manufactured by using reconstituted milk skim milk powder and 1-2\% of different vegetable oils. The chemical, rheological, microbiological, and organoleptic properties of labneh manufactured by using vegetable oils were determined. There were slight significant differences in moisture, protein, total nitrogen, fat, and ash values in labneh treatments while $\mathrm{pH}$ values decreased gradually until 21 days may be due to an increase in the acidity. Total viable count was gradually increased during storage up to 14 days, then they decreased in 21 days period of storage in treatments. Lactobacillus count was gradually increased during storage up to 21 days. Coliform and staphylococcus bacteria were not detected, while yeasts and molds were detected and reached a maximum at 21 days. Fracture, hardness, adhesiveness, cohesiveness springiness, and chewiness of fresh labneh treatments were determined. Organoleptic properties showed that with the increase in the percentage of vegetable oils, the total score of labneh treatments decreased, except for sesame oil. On other hand, all labneh treatments were sensually acceptable. The best treatment was fortified with $1 \%$ sunflower oil, it had a total score higher than the control treatment. Fortified labneh with virgin olive, sunflower, corn, and sesame oils can be considered as a new product with functional properties.
\end{abstract}

Keywords: Vegetable oils; Labneh; Chemical analysis; Rheological properties; Microbiological properties.

\section{Introduction}

Labneh is a conventional product of fermented milk. It is a popular food in different places of the world, particularly in the regions of the Middle East, where it plays an important role in the family diet. Over the last decade, it has grown in popularity. Nutritional benefits and storage are the economic significance of the features has increased [1]. Labneh is considered an intermediate product between fermented milks and immature cheeses with high water content [2].

In food products, vegetable oils play important functional and sensory roles, and they act as carriers of fatsoluble vitamins (A, D, E, and K). They also include an essential fatty acid, responsible for growth [3, 4]. As a source of health oils, sesame oil with a distinctive flavour is very common in many Asian and European countries and widely used in the food industry. It has a high volume of polyunsaturated fat, abundant compounds of lignans and alpha tocopherol. The composition of fatty acids contains $43 \%$ oleic and linoleic acids, $9 \%$ palmitic fatty acids and $4 \%$ stearic acid [5].

The importance of virgin olive oil is related to its high levels of mono-unsaturated fatty acids (mainly oleic acid) and to the presence of minor components including aliphatic and tri-terpenic alcohols, sterols, hydrocarbons, volatile compounds, and several antioxidants [6]. Abou and Gamal [7], used some aromatic oils to goat, milk, and replacement of goat's milk fat with corn oil or sunflower oils. Therefore, the objectives of this study were to determine chemical, rheological, microbiological, and organoleptic properties for healthy labneh manufactured by using virgin olive, sunflower, corn and sesame oils.

\section{Material and Method}

\subsection{Material}

Skim milk powder: Low heat food grad imported from USA produced by Dairy America/California USA obtained from El Sherbiny's company Reconstitute 1/10. 


\begin{tabular}{l|l|l|l}
\hline Fat & Protein & Moisture & Lactose \\
\hline $1.25 \%$ & $34 \%$ & $4 \%$ & $51 \%$ \\
\hline
\end{tabular}

Starter: Yoghurt starter culture consist of Streptococcus salvarius Sub sp. thermophilus and Lactobacillus delbreuckii sub sp bulgaricus obtained from Hansen, s Lab, Denmark. Emulsifier: Di sodium hydrogen orthophosphate anhydrous (DSP) was obtained from producer ADWIC-Egypt. Salt: Commercial clean good grade of cooking salt (sodium chloride) obtained from the local market. Olive oil: virgin olive oil obtained from El-Dorra market in New Damietta that obtained from Suez Sinai added to labneh at a ratio 1-2\%. Sunflower oil and Corn oil: Obtained from El Sherbiny's company in Damietta and it was produced by Arma Company, Egypt. Sesame oil: Obtained from Almasria Company for natural oils, Cairo, Egypt, and Cloth bags of labneh: Obtained from local market in Damietta government.

\subsection{Methods}

Traditional Labneh manufacturing according to Abou and Gamal [7].

\subsection{Manufacturing Treatments}

In this treatment, 5 kilograms of recombined skim milk were aged for 8 hours in the refrigerator at a temperature of $4^{\circ} \mathrm{C}$, then added $0.10 \%$ DSP, stirring well in the mixer, then adding the milk fat at ratio $1 \%$ as equal $12.195 \mathrm{~g} \backslash \mathrm{L}$ and stirring again then pasteurization at $90^{\circ} \mathrm{C}$ for 10 minutes, then cooling at $42^{\circ} \mathrm{C}$, and adding the starter at the rate of $2 \%$, then incubating at $42^{\circ} \mathrm{C}$ for 4 hours, after complete coagulation, the curd was salted at a rate of $0.5 \% \mathrm{NaCl}$, then cutting 1 X 1 X $1 \mathrm{~cm}$, the samples were filtered in cloth bags for 14-18 hours without any pressing, then packing and preserving in the refrigerator at $5^{\circ} \mathrm{C}$ for 21 days and in a treatment of $2 \%$ The same steps, but with an addition of $2 \%$ fat, equivalent to $24.39 \mathrm{~g}$ fat $/ \mathrm{L}$.

- Treatment control 1 with $1 \%$ milk fat namely Con 1 .

- $\quad$ Treatment control 2 with $2 \%$ milk fat namely Con2.

Manufacture treatments by using vegetable oils; The treatments were divided into:

- $\quad$ Treatment O1 with $1 \%$ olive oil.

- $\quad$ Treatment C1 with $1 \%$ corn oil.

- Treatment S1 with $1 \%$ sunflower oil.

- $\quad$ Treatment M1 with $1 \%$ sesame oil.

- $\quad$ Treatment $\mathrm{O} 2$ with $2 \%$ olive oil.

- Treatment C2 with $2 \%$ olive oil.

- $\quad$ Treatment S2 with 2\% Sunflower oil.

- $\quad$ Treatment M2 with 2\% Sesame oil.

Where, in each treatment, 5 kilograms of milk are aged and sorted. Each treatment is recovered separately for 8 hours in the refrigerator at a temperature of $4^{\circ} \mathrm{C}$, then pasteurization at $90^{\circ} \mathrm{C}$ for 10 minutes, then cooling at $42^{\circ} \mathrm{C}$, then adding $0.15 \%$ DSP, then adding oil at a rate of $1-2 \%$ and stirring in the mixer for 10 minutes, then adding the starter at a rate of $2 \%$, then incubating at a temperature of $42^{\circ} \mathrm{C}$ for 4 hours, after complete coagulation, the curd was salted at a rate of $0.5 \% \mathrm{NaCl}$, then the curd is cut into small parts and filtered in cloth bags for 16-18 hours, then packing and preserving in the refrigerator at $5^{\circ} \mathrm{C}$ for 21 days.

Labneh sampling: Labneh samples were collected at zero time (fresh labneh, 7, 14 and 21 days for chemical, microbiological, rheological, and organoleptic analyzes.

\subsection{Microbiological Analysis}

Counting of Total bacterial count (TBC): TBC was done suitable dilution $\left(10^{4}-10^{6}\right)$ in duplicates using Nutrient agar medium [8] by using pouring plat methods [9].

Counting of Lactobacillus count: Lactobacillus bacterial counts was determined by using MRS agar medium according to De Man, et al. [10]. All plates were incubated under anaerobic conditions at $40^{\circ} \mathrm{C}$ for $48 \mathrm{~h}$.

Coliform bacteria test: One $\mathrm{ml}$ of each dilution was transferred to test tubes containing Durham tubes in three replicates; added 6-8ml of MacConkey Broth medium then placed test tubes to incubate at $37^{\circ} \mathrm{C}$ for $24 \mathrm{~h}$. The tubes which have gas production and yellow color is considered positive results according to Marshall [11].

\subsection{Chemical Analysis}

pH: The $\mathrm{pH}$ value of labneh was determined by using glass electrode $\mathrm{pH}$ meter (Model 810 Fisher Scientific) according to Association of official Agriculture Chemists AOAC [12].

Moisture content: The moisture content of labneh was detected according to the method described [12].

Fat content of labneh treatments: The fat content was determined by using the Soxhelt, method as described by Association of official Agriculture Chemists AOAC [12].

Fat content of whey: The whey of fresh labneh treatments according to Rose-Gotallib method [12].

Total nitrogen content (TN): The total nitrogen content was determined by the macro kjeldahl method as described by Association of official Agriculture Chemists AOAC [12], and protein factors 6.38.

Ash content: The ash content of labneh samples muffle furnace at $550^{\circ} \mathrm{C}$ for $6 \mathrm{~h} \mathrm{[12].}$ 


\subsection{Some Rheological Properties of labneh}

Curd tension: The method of Chandrasekhara, et al. [13] was used to measure the curd tension as follows:

The used apparatus consisted of knives of constant weight $(5 \mathrm{gm})$ has shaped with a needle in the middle ending with a hook, and a wire crossing a freely rotating wheel attached to knife at one end a pan $(5 \mathrm{gm})$ at the other. The knife was placed in a $100 \mathrm{ml}$ beaker. The Milk was heated to $37^{\circ} \mathrm{C}$ and inoculated with starter, then it was added to the beaker and incubated at $37^{\circ} \mathrm{C}$ until coagulation. The curd tension was measured after holding the curd in the refrigerator overnight. It is expressed as weight in grams required removing the knife from the prepared curd.

Syneresis: Syneresis of the resultant curd measured as the volume of drained whey, and calculated as the percent of the volume of whey strained from curd as the method showed by [14].

Textural characteristics: The samples submitted by Labneh were $30 \mathrm{~mm}$ in diameter and $20 \mathrm{~mm}$ in height. A TA15-45 Perspex cone with a penetration of $10 \mathrm{~mm}$ at $1 \mathrm{~mm} / \mathrm{s}$ was used as the robe. Samples could balance before testing for approximately 30-45 minutes at ambient temperature. Textural characteristics of measurement using user interface software (FTC TMS pro, USA). The following textural parameters were determined according to the method of Szczesniak, et al. [15] hardness (force needed to attain a given deformation), cohesiveness (the strength of internal bonds making up the body of the product), springiness is the rate at which a deformed material return to its original shape on removal of the deforming force, adhesiveness (force required to pull probe from sample), chewiness (energy needed to chew a food product to a state where it is ready for swallowing: hardness $x$ cohesiveness $\times$ adhesiveness and gumminess is the energy required to disintegrate a semisolid food for swallowing.

Organoleptic evaluation: Sensory evaluation was carried out for labneh treatments, using a score scheme (20, 30, 20 and 30 points) for appearance, body and texture, odor, and flavor, respectively by a panel of 10 trained Jude's of stuff members at Dairy Department, according to score card suggested by Keating and White [16] with modifications.

Statistical analysis: The obtained results were statistically analyzed using a software package [17] based on analysis of variance. When F-test was significant, least significant difference (LSD) was calculated according to Duncan [18], for the comparison between means. The data presented, in the tables, are the mean $( \pm$ standard deviation) of 3 experiments.

\section{Results}

\subsection{Physco-Chemical Composition of labneh Treatments with 1-2\% Vegetable Oils}

pH values: Data in Table (1) showed Significant differences between treatments in $\mathrm{pH}$ the highest treatment was Con 1 recorded 4.17 followed by Con2 treatment that recorded 4.16. The lowest treatment was M1 recorded 4.01 followed by $\mathrm{O} 1$ treatment that recorded 4.02. In addition, significant differences were observed in the $\mathrm{pH}$ of the different labneh, either when fresh or during the storage period. During storage, $\mathrm{pH}$ values decreased gradually until 21 days may be due to increase the acidity. The Change in $\mathrm{pH}$ is a crucial factor as it affects shelf life and the acceptability of labneh. It is evident that $\mathrm{pH}$ values of the treated labneh decreased only slightly with the storage period. These results agreed with those obtained by Abbas and Osman [19], who reported that the pH decreased gradually during storage period and titratable acidity, increased gradually during the storage period. The data is similar those of Guler [20], Abou and Gamal [7] and Senel, et al. [21]. Generally, in concentrated yogurt such as labneh, acidity and $\mathrm{pH}$ values vary depending on the starter culture and draining conditions. For this reason, in terms of acidity and $\mathrm{pH}$ there have been different values in the literature. These results were in accordance with Ersoz, et al. [22], Zaky, et al. [23] and Elama, et al. [24].

Moisture content: Data in Table (1) showed that there were Significant differences between treatments the highest treatment was S1 treatment followed by Con1 treatment that recorded $76.13 \%$ and $75.76 \%$, respectively. The lowest treatment was Con2 followed by $\mathrm{O} 2$ treatment that recorded $72.73 \%$ and $74.13 \%$, respectively. In addition, significant differences $(\mathrm{P} \leq 0.05)$ were observed in the moisture content of the different labneh, either when fresh or during the storage period. During storage, moisture slightly increased and the reason could be due to TS loss. Differ from, Mutlag and Hassan [25] reported that there were no observable differences in moisture of labneh produced by addition of three different essential oils. The data is also similar those of Mehaia and El Khadragy [26], who reported that the moisture of labneh ranged between $74-78 \%$.

Ash content: From results presented in Table (1) we found slight significant differences between labneh treatments in ash percentage. The highest treatment was Con 2 treatment recorded $1.43 \%$ followed by $\mathrm{O} 2$ treatment recorded $1.37 \%$. The lowest treatment was Con 1 recorded $0.90 \%$ followed by $\mathrm{O} 1$ treatment recorded $0.92 \%$. Ash proportions are similar to Saad, et al. [27] and Abou Jaoude, et al. [28]. In addition, there were significant differences $(\mathrm{P} \leq 0.05)$ were observed in of the different labneh, either when fresh or during the storage period. During storage, ash content decreased slightly could be due to the TS loss. Differ from Ghoneem, et al. [29] reported that ash content increase during storage period. 
Table-1. Chemical composition of labneh treatments during refrigerated storage

\begin{tabular}{|c|c|c|c|c|c|c|}
\hline Treatment & $\begin{array}{l}\text { Storage Period } \\
\text { (Days) }\end{array}$ & $\mathbf{p H}$ & Moisture \% & Ash \% & Fat\% & TN\% \\
\hline \multirow[t]{4}{*}{ Con1 } & Zero & $4.40^{\mathrm{a} A}$ & $75.39^{\mathrm{bcBC}}$ & $1.03^{\mathrm{deA}}$ & $4.96^{\mathrm{abAB}}$ & $2.951^{\mathrm{aA}}$ \\
\hline & 7 & $4.12^{\mathrm{a} B}$ & $75.74^{\mathrm{aB}}$ & $0.50^{\mathrm{cA}}$ & $4.29^{\mathrm{bcB}}$ & $2.894^{\mathrm{aA}}$ \\
\hline & 14 & $4.12^{\mathrm{aB}}$ & $76.77^{\mathrm{aA}}$ & $1.04^{\mathrm{bcdA}}$ & $4.21^{\mathrm{deB}}$ & $2.967^{\mathrm{a} A}$ \\
\hline & 21 & $4.05^{\mathrm{bcB}}$ & $75.13^{\mathrm{bcC}}$ & $1.04^{\mathrm{cA}}$ & $5.38^{\mathrm{bcdeA}}$ & $2.863^{\mathrm{abA}}$ \\
\hline \multirow[t]{4}{*}{01} & Zero & $4.04^{\mathrm{gA}}$ & $75.79^{\mathrm{bA}}$ & $0.84^{\mathrm{eB}}$ & $4.40^{\mathrm{abA}}$ & $2.808^{\mathrm{bA}}$ \\
\hline & 7 & $4.03^{\mathrm{bA}}$ & $75.04^{\mathrm{bcA}}$ & $0.83^{\mathrm{bcB}}$ & $4.68^{\mathrm{bcA}}$ & $2.708^{\mathrm{cdB}}$ \\
\hline & 14 & $4.01^{\mathrm{cdA}}$ & $75.46^{\mathrm{bA}}$ & $1.19^{\mathrm{abcdA}}$ & $4.11^{\mathrm{eA}}$ & $2.680^{\mathrm{cB}}$ \\
\hline & 21 & $3.99^{\mathrm{cdA}}$ & $75.61^{\mathrm{bcA}}$ & $0.80^{\mathrm{cB}}$ & $4.43^{\mathrm{deA}}$ & $2.746^{\mathrm{bcAB}}$ \\
\hline \multirow[t]{4}{*}{ S1 } & Zero & $4.36^{\mathrm{bA}}$ & $76.76^{\mathrm{aA}}$ & $0.90^{\mathrm{e} B}$ & $4.39^{\mathrm{abA}}$ & $2.761^{\mathrm{bcA}}$ \\
\hline & 7 & $4.02^{\mathrm{bC}}$ & $75.41^{\mathrm{abB}}$ & $0.73^{\mathrm{bcB}}$ & $3.59^{\mathrm{cA}}$ & $2.738^{\mathrm{bcA}}$ \\
\hline & 14 & $4.06^{\mathrm{bB}}$ & $75.64^{\mathrm{bAB}}$ & $1.44^{\mathrm{aA}}$ & $4.39^{\mathrm{cde} A}$ & $2.769^{b c A}$ \\
\hline & 21 & $4.01^{\mathrm{bcdC}}$ & $76.72^{\mathrm{aAB}}$ & $0.81^{\mathrm{cB}}$ & $3.88^{\mathrm{eA}}$ & $2.764^{\mathrm{abcA}}$ \\
\hline \multirow[t]{4}{*}{ C1 } & Zero & $4.2^{\mathrm{dA}}$ & $75.11^{\mathrm{cdA}}$ & $0.96^{\mathrm{aA}}$ & $4.00^{\mathrm{bA}}$ & $2.714^{\mathrm{cA}}$ \\
\hline & 7 & $4.00^{\mathrm{bB}}$ & $75.09^{\mathrm{bcA}}$ & $1.31^{\mathrm{aA}}$ & $4.41^{\mathrm{bcA}}$ & $2.710^{\mathrm{cdA}}$ \\
\hline & 14 & $4.02^{\mathrm{cdB}}$ & $73.29^{\mathrm{cB}}$ & $1.25^{\mathrm{abcA}}$ & $5.54^{\mathrm{bA}}$ & $2.714^{b c A}$ \\
\hline & 21 & $4.01^{\mathrm{bcdB}}$ & $75.18^{\mathrm{bcA}}$ & $0.98^{\mathrm{cA}}$ & $5.07^{\mathrm{cdeA}}$ & $2.710^{\mathrm{bcA}}$ \\
\hline \multirow[t]{4}{*}{ M1 } & Zero & $4.02^{\mathrm{gAB}}$ & $74.43^{\mathrm{eAB}}$ & $0.93^{\mathrm{eB}}$ & $4.37^{\mathrm{abA}}$ & $2.894^{\mathrm{aAB}}$ \\
\hline & 7 & $4.03^{\mathrm{bA}}$ & $73.92^{\mathrm{eB}}$ & $0.73^{\mathrm{bcB}}$ & $4.81^{\mathrm{bcA}}$ & $2.880^{\mathrm{aAB}}$ \\
\hline & 14 & $4.02^{\mathrm{cdAB}}$ & $75.42^{\mathrm{bA}}$ & $1.4^{\mathrm{abA}}$ & $4.48^{\text {bcdeA }}$ & $2.843^{\mathrm{abB}}$ \\
\hline & 21 & $3.97^{\mathrm{dB}}$ & $75.70^{\mathrm{abcA}}$ & $0.99^{\mathrm{cB}}$ & $3.83^{\mathrm{eA}}$ & $2.962^{\mathrm{aA}}$ \\
\hline \multirow[t]{4}{*}{ Con2 } & Zero & $4.23^{\mathrm{cA}}$ & $71.74^{\mathrm{fB}}$ & $1.79^{\mathrm{a} A}$ & $5.71^{\mathrm{aB}}$ & $2.716^{\mathrm{cA}}$ \\
\hline & 7 & $4.14^{\mathrm{aB}}$ & $71.73^{\mathrm{fB}}$ & $1.62^{\mathrm{a} A}$ & $7.59^{\mathrm{aA}}$ & $2.747^{\mathrm{bcA}}$ \\
\hline & 14 & $4.15^{\mathrm{aB}}$ & $73.50^{\mathrm{cA}}$ & $0.81^{\mathrm{dB}}$ & $7.49^{\mathrm{aA}}$ & $2.669^{\mathrm{cA}}$ \\
\hline & 21 & $4.14^{\mathrm{aB}}$ & $73.95^{\mathrm{dA}}$ & $1.5^{\mathrm{abA}}$ & $8.31^{\mathrm{a} A}$ & $2.689^{b c A}$ \\
\hline \multirow[t]{4}{*}{$\mathbf{O 2}$} & Zero & $4.12^{\mathrm{eA}}$ & $73.93^{\mathrm{eB}}$ & $1.69^{\mathrm{ab} \mathrm{A}}$ & $4.16^{\mathrm{abB}}$ & $2.915^{\mathrm{aA}}$ \\
\hline & 7 & $4.05^{\mathrm{bB}}$ & $73.55^{\mathrm{eB}}$ & $1.55^{\mathrm{a} B}$ & $4.99^{\mathrm{bAB}}$ & $2.909^{\mathrm{aA}}$ \\
\hline & 14 & $3.99^{\mathrm{dC}}$ & $74.05^{\mathrm{cB}}$ & $0.88^{\mathrm{cdD}}$ & $5.21^{\text {bcdeAB }}$ & $2.945^{\mathrm{aA}}$ \\
\hline & 21 & $3.98^{\mathrm{dC}}$ & $74.97^{\mathrm{cA}}$ & $1.34^{\mathrm{bC}}$ & $6.69^{\mathrm{bA}}$ & $2.885^{\mathrm{abA}}$ \\
\hline \multirow[t]{4}{*}{ S2 } & Zero & $4.14^{\mathrm{eA}}$ & $74.48^{\mathrm{deB}}$ & $1.34^{\mathrm{c} \mathrm{A}}$ & $4.38^{\mathrm{abA}}$ & $2.721^{\mathrm{cC}}$ \\
\hline & 7 & $4.04^{\mathrm{bB}}$ & $74.63^{\mathrm{dAB}}$ & $0.86^{\mathrm{bc} \mathrm{B}}$ & $4.59^{\mathrm{bcA}}$ & $2.833^{\mathrm{bcc}}$ \\
\hline & 14 & $4.04^{\mathrm{bcB}}$ & $75.19^{\mathrm{bAB}}$ & $0.90^{\mathrm{cdB}}$ & $5.13^{\text {bcdeA }}$ & $2.813^{\mathrm{abcB}}$ \\
\hline & 21 & $4.05^{\mathrm{bB}}$ & $76.24^{\mathrm{abA}}$ & $0.88^{\mathrm{cB}}$ & $5.54^{\mathrm{bcdA}}$ & $2.959^{\mathrm{a} A}$ \\
\hline \multirow[t]{4}{*}{$\mathrm{C2}$} & Zero & $4.08^{\mathrm{fA}}$ & $74.31^{\mathrm{eC}}$ & $1.41^{\mathrm{bc} \mathrm{A}}$ & $4.06^{\mathrm{bB}}$ & $2.587^{\mathrm{dB}}$ \\
\hline & 7 & $4.03^{\mathrm{bBC}}$ & $74.91^{\mathrm{cdB}}$ & $0.82^{\text {bc B }}$ & $5.49^{\mathrm{bA}}$ & $2.634^{\mathrm{dB}}$ \\
\hline & 14 & $4.01^{\mathrm{cdC}}$ & $75.31^{\mathrm{bB}}$ & $0.95^{\mathrm{cdB}}$ & $5.38^{\mathrm{bcA}}$ & $2.741^{\mathrm{bcA}}$ \\
\hline & 21 & $4.04^{\mathrm{bcB}}$ & $76.24^{\mathrm{abA}}$ & $0.8^{\mathrm{cB}}$ & $5.503^{\mathrm{bcdA}}$ & $2.565^{\mathrm{cB}}$ \\
\hline \multirow[t]{4}{*}{ M2 } & Zero & $4.15^{\mathrm{eA}}$ & $74.52^{\mathrm{deC}}$ & $1.30^{\mathrm{cd} \mathrm{B}}$ & $4.62^{\mathrm{abB}}$ & $2.902^{\mathrm{aA}}$ \\
\hline & 7 & $4.05^{\mathrm{bB}}$ & $75.28^{\mathrm{bcB}}$ & $0.88^{\mathrm{bC}}$ & $5.23^{\mathrm{bAB}}$ & $2.833^{\mathrm{abA}}$ \\
\hline & 14 & $4.04^{\mathrm{bcB}}$ & $75.94^{\mathrm{abA}}$ & $0.84^{\mathrm{dC}}$ & $5.30^{\text {bcdA }}$ & $2.931^{\mathrm{aA}}$ \\
\hline & 21 & $4.04^{\mathrm{bcB}}$ & $76.13^{\mathrm{abA}}$ & $1.7^{\mathrm{aA}}$ & $6.42^{\mathrm{bcA}}$ & $2.336^{\mathrm{dB}}$ \\
\hline
\end{tabular}

Small latter $=$ (treatment effect in the same time storage); Capital latter $=($ storage effect in the same treatment $)$

Con1 $=$ Treatment with $1 \%$ milk fat, $\mathbf{O 1}=$ Treatment with $1 \%$ olive oil, $\mathbf{S 1}=$ Treatment with $1 \%$ sunflower oil, $\mathbf{C 1}=$ Treatment with $1 \%$ corn oil, $\mathbf{M 1}=$ Treatment with $1 \%$ sesame oil, $\mathbf{C o n} 2=$ Treatment with $2 \%$ milk fat, $\mathbf{O 2}=$ Treatment with $2 \%$ olive oil, $\mathbf{S 2}=$ Treatment with $2 \%$ sunflower oil, $\mathbf{C 2}=$ Treatment with $2 \%$ corn oil, $\mathbf{M 2}=$ Treatment with $2 \%$ sesame oil.

Fat content: From results presented in Table (1) there were slight significant differences between labneh treatments in fat percentage. The highest treatment was Con2 treatment recorded 7.27\% followed by M2 treatment recorded 5.39\%. The lowest treatment was S1 treatment recorded 4.06\% followed by M1 treatment recorded 4.37\%. In addition to significant differences $(\mathrm{P} \leq 0.05)$ were observed in fat of the different labneh, either when fresh or during the storage period. During storage, fat content increased slightly. Similarly, Ismail, et al. [30] also reported that there were no observable differences in fat of labneh produced by addition of six different essential oils. The data is also similar those of Tamime and Robinson [31], Mutlag and Hassan [25] and Ghoneem, et al. [29].

Total nitrogen content: Table (1) showed Significant differences between treatments in TN the highest treatment was Con 1 recorded $2.91 \%$ followed by M1 treatment that recorded $2.89 \%$. The lowest treatment was Con2 recorded $2.70 \%$ followed by $\mathrm{C} 1$ treatment that recorded $2.71 \%$. The data is also similar Ayana and El-Shabraw [32] who reported that the $\mathrm{TN}$ of labneh ranged between 1.78-2.39\%. In addition, significant differences $(\mathrm{P} \leq 0.05)$ were observed in the TN content of the different labneh, either when fresh or during the storage period. During storage, slightly increased until 14 days then decreased slightly in 21 days. The data is also similar Ghoneem, et al. [29] who reported TN increased during storage until 21 days and the $\mathrm{TN}$ of labneh ranged between 1.36-1.59\%. These results agreed with Mutlag and Hassan [25], Thabet, et al. [8] and Abbas, et al. [33]. 
Fat content of whey of fresh labneh treatments: From Table (2) the results showed fat contents that loosed in whey of fresh labneh treatments. The highest treatment was $\mathrm{C} 2$ recorded $0.567 \%$ followed by $\mathrm{O} 2$ treatment recorded $0.49 \%$. The lowest treatment $\mathrm{C} 1$ that recorded $0 \%$. It is noticeable that the labneh treatments of $1 \%$ are less in the percentage of lost fat in the whey as it is Con1 treatment recorded $0.296 \%$, O1 treatment recorded $0.151 \%$, S1 treatment recorded 0.045 , M1 treatment recorded 0.064 and $\mathrm{C} 1$ treatment non detected fat content. While the percentage of lost fat increases by $2 \%$ addition. We found Con 1 treatment recorded $0.296 \%, 01$ treatment recorded $0.49 \%$, S1 treatment recorded $0.23 \%$, and $\mathrm{C} 1$ treatment recorded $0.567 \%$. M1 treatment recorded $0.109 \%$. These results showed the higher the added fat percentage, the greater the lost fat percentage, but there is stability in the lost fat percentage in the control treatment $1-2 \%$.

Table-2. Fat content of whey of fresh labneh treatments

\begin{tabular}{|c|c|}
\hline Treatments & Loss Fat in whey \% \\
\hline Con1 & $0.296^{\mathrm{abc}}$ \\
\hline 01 & $0.151^{\mathrm{bc}}$ \\
\hline S1 & $0.045^{\mathrm{c}}$ \\
\hline C1 & $0^{\mathrm{c}}$ \\
\hline M1 & $0.064^{\mathrm{c}}$ \\
\hline Con2 & $0.29^{\mathrm{abc}}$ \\
\hline $\mathbf{O 2}$ & $0.49^{\mathrm{ab}}$ \\
\hline $\mathbf{S 2}$ & $0.23^{\mathrm{abc}}$ \\
\hline $\mathrm{C2}$ & $0.567^{\mathrm{a}}$ \\
\hline M2 & $0.109^{c}$ \\
\hline
\end{tabular}

\subsection{Microbiological Properties of labneh Treatments During Storage}

Total bacterial count: Data presented in Table (3) showed Significant differences between treatments the highest treatment was M2 recorded $6.36 \log ^{10} \mathrm{cfu} \mathrm{g}^{-1}$ followed by Con2 treatment that recorded $6.20 \log ^{10} \mathrm{cfu} \mathrm{g}^{-1}$. The lowest treatment was Con1 recorded $5.57 \log ^{10} \mathrm{cfu}$ g-1 followed by C1 treatment that recorded $5.59 \log ^{10} \mathrm{cfu} \mathrm{g}^{-}$ 1 . The data is also similar Abbas, et al. [33] used 1-2\% high virgin olive oil who reported the results from 4.5-7 $\log ^{10} \mathrm{cfu}$ g-1 and the results differ from El-Sayed, et al. [34] who reported the results from $8-9.9 \log ^{10} \mathrm{cfu} \mathrm{g}^{-1}$. The obtained results suggest that bacterial population was stimulated by adding oil this may be due to high nutritional composition of oil such as essential fatty acids and vitamins. Moreover, increases in the level adding oil led to enhance in bacterial counts. When added $2 \%$ led to increase the bacterial count except the virgin olive oil when added $2 \%$ led to decrease in bacterial counts may be due to its high components of polyphenols and antioxidants. On the other hand, the high bacterial counts of such treatments may be due to increase the counts of starter cultures and probiotic bacteria that found in labneh samples. The microbiological changes of labneh through 21 days of storage. Total viable count was gradually increased during storage up to 14 day, then they decreased in 21 days period of storage in treatments. These results agreed to Mutlag and Hassan [25], who found that total viable counts were gradually increased up to 7 days of storage then also decreased the results similar Abbas, et al. [33] who used 1-2\% high Virgin Olive oil.

Lactobacillus count: Data in Table (3) showed Significant differences between treatments the highest treatment was S2 recorded $7.68 \log ^{10} \mathrm{cfu} \mathrm{g}^{-1}$ followed by $\mathrm{C} 1$ treatment that recorded $7.41 \log ^{10} \mathrm{cfu} \mathrm{g}^{-1}$. The lowest treatment was $\mathrm{S} 1$ treatment recorded $6.60 \log ^{10} \mathrm{cfu} \mathrm{g}^{-1}$ followed by $\mathrm{O} 1$ treatment that recorded $6.88 \log ^{10} \mathrm{cfu} \mathrm{g}^{-1}$. Abou and Gamal [7], reported that addition of some aromatic and essential oils to yoghurt and labneh had stimulatory effect on lactic acid bacteria by enhancing their growth and acid production. The obtained results suggest that bacterial population was stimulated by adding oil this may be due to high nutritional composition of oil such as essential fatty acids and vitamins. Moreover, increases in the level adding oil led to enhance in lactic acid bacterial counts. When added 2\% led to increase the bacterial count. The data is also similar Abbas, et al. [33] used 1-2\% high Virgin olive oil who reported the results from $5.2^{-8} \log ^{10} \mathrm{cfu} \mathrm{g}^{-1}$ and El-Sayed, et al. [34] who reported the presence of essential fatty and vitamins acid in the Moringa oleifera improved the growth of the organisms. The microbiological changes of labneh through 21 days of storage. Lactobacillus count were gradually increased during storage up to 21 days. These results agreed to El-Sayed, et al. [34] but differ from Abbas, et al. [33] who reported that Lactobacillus counts increased up to 7 days of storage then decreased until 21 days.

Yeast and mould counts: The quality and the shelf life of labneh evaluated with yeast and mould counts. Data in Table (3) showed significant differences between treatments the highest treatment was O1 recorded $4.30 \log { }^{10} \mathrm{cfu}$ $\mathrm{g}^{-1}$ followed by M1 treatment that recorded $3.89 \log ^{10} \mathrm{cfu} \mathrm{g}^{-1}$. The lowest treatment was Con1 recorded $3.12 \log ^{10} \mathrm{cfu}^{-1}$ $\mathrm{g}^{-1}$ followed by $\mathrm{C} 1$ treatment that recorded $3.25 \log ^{10} \mathrm{cfu} \mathrm{g}^{-1}$. Moulds and yeasts were gradually increased during storage up to 21 days. It is noticeable that the numbers of moulds and yeasts decreased in treatments $2 \%$ with virgin olive oil and sesame oil counter to treatments with $1 \%$ virgin olive oil and sesame oil. Nazzaro, et al. [35] and Elama, et al. [24] reported that virgin olive oil and sesame oil containing phenolic and flavonoid compounds that are responsible for their antimicrobial properties. These results agreed to Al-Kadamany, et al. [36] and El-Sayed, et al. [34]. 
Table-3. Total bacterial count of labneh treatments during storage

\begin{tabular}{|c|c|c|c|c|}
\hline Treatments & Storage Period (Days) & TBC & Lactobacillus count & Molds and yeasts \\
\hline \multirow[t]{4}{*}{ Con1 } & Zero & $5.24^{\mathrm{abcB}}$ & $6.44^{\mathrm{abc}}$ & $2.34^{\mathrm{bC}}$ \\
\hline & 7 & $4.75^{\mathrm{fB}}$ & $6.27^{\mathrm{cD}}$ & $3.15^{\mathrm{cB}}$ \\
\hline & 14 & $6.36^{\mathrm{cdA}}$ & $7.07^{\mathrm{dB}}$ & $3.48^{\mathrm{d} A}$ \\
\hline & 21 & $5.91^{\mathrm{aA}}$ & $8.21^{\mathrm{bA}}$ & $3.53^{\mathrm{dA}}$ \\
\hline \multirow[t]{4}{*}{01} & Zero & $5.08^{\mathrm{abcBC}}$ & $6.02^{\mathrm{bD}}$ & $3.34^{\mathrm{aC}}$ \\
\hline & 7 & $4.87^{\mathrm{efC}}$ & $6.23^{\mathrm{cC}}$ & $4.36^{\mathrm{aB}}$ \\
\hline & 14 & $6.42^{\mathrm{cdA}}$ & $7.03^{\mathrm{dB}}$ & $4.64^{\mathrm{aA}}$ \\
\hline & 21 & $6.10^{\mathrm{aAB}}$ & $8.21^{\mathrm{bA}}$ & $4.85^{\mathrm{aA}}$ \\
\hline \multirow[t]{4}{*}{ S1 } & Zero & $5.44^{\mathrm{abc} \mathrm{BC}}$ & $5.30^{\mathrm{cC}}$ & $3.16^{\mathrm{aB}}$ \\
\hline & 7 & $4.73^{\mathrm{fC}}$ & $6.34^{\mathrm{cB}}$ & $3.27^{\mathrm{bcbB}}$ \\
\hline & 14 & $6.09^{\mathrm{d} \mathrm{AB}}$ & $7.14^{\text {cdA }}$ & $4.30^{\mathrm{bA}}$ \\
\hline & 21 & $6.45^{\mathrm{aA}}$ & $7.62^{\mathrm{cA}}$ & $4.69^{\mathrm{aA}}$ \\
\hline \multirow[t]{4}{*}{ C1 } & Zero & $4.94^{\mathrm{bcdA}}$ & $5.40^{\mathrm{cC}}$ & $2.35^{\mathrm{bB}}$ \\
\hline & 7 & $5.40^{\mathrm{deA}}$ & $8.48^{\mathrm{a} A}$ & $3.40^{\mathrm{bcA}}$ \\
\hline & 14 & $6.40^{\mathrm{cdA}}$ & $7.23^{\mathrm{cdB}}$ & $3.74^{\mathrm{cA}}$ \\
\hline & 21 & $5.61^{\mathrm{aA}}$ & $8.55^{\mathrm{aA}}$ & $3.50^{\mathrm{dA}}$ \\
\hline \multirow[t]{4}{*}{ M1 } & Zero & $5.64^{\mathrm{abAB}}$ & $5.30^{\mathrm{cC}}$ & $3.14^{\mathrm{aC}}$ \\
\hline & 7 & $5.30^{\mathrm{defB}}$ & $7.14^{\mathrm{bA}}$ & $3.69^{\mathrm{bB}}$ \\
\hline & 14 & $6.20^{\mathrm{dA}}$ & $6.90^{\mathrm{dB}}$ & $3.85^{\mathrm{cB}}$ \\
\hline & 21 & $6.07^{\mathrm{aA}}$ & $8.41^{\mathrm{abA}}$ & $4.87^{\mathrm{aA}}$ \\
\hline \multirow[t]{4}{*}{ Con2 } & Zero & $4.22^{\mathrm{dC}}$ & $5.51^{\mathrm{cC}}$ & $2.30^{\mathrm{bB}}$ \\
\hline & 7 & $6.89^{\mathrm{aAB}}$ & $7.21^{\mathrm{bB}}$ & $3.46^{\mathrm{bcA}}$ \\
\hline & 14 & $7.21^{\mathrm{aA}}$ & $7.96^{\mathrm{abA}}$ & $3.49^{\mathrm{dA}}$ \\
\hline & 21 & $6.49^{\mathrm{aB}}$ & $7.76^{\mathrm{cA}}$ & $4.08^{\mathrm{bcA}}$ \\
\hline \multirow[t]{4}{*}{$\mathbf{O 2}$} & Zero & $5.20^{\mathrm{abcB}}$ & $5.28^{\mathrm{cD}}$ & $3.45^{\mathrm{aB}}$ \\
\hline & 7 & $5.80^{\mathrm{cd} \mathrm{A}}$ & $7.59^{\mathrm{bC}}$ & $3.70^{\mathrm{bAB}}$ \\
\hline & 14 & $5.63^{\mathrm{eA}}$ & $8.16^{\mathrm{aA}}$ & $3.80^{\mathrm{cA}}$ \\
\hline & 21 & $5.79^{\mathrm{a} A}$ & $7.83^{\mathrm{cB}}$ & $3.65^{\mathrm{dAB}}$ \\
\hline \multirow[t]{4}{*}{ S2 } & Zero & $4.69^{\mathrm{cdC}}$ & $6.62^{\mathrm{aC}}$ & $3.39^{\mathrm{aB}}$ \\
\hline & 7 & $6.08^{\mathrm{bcB}}$ & $7.41^{\mathrm{bB}}$ & $3.36^{\mathrm{bcB}}$ \\
\hline & 14 & $6.63^{\mathrm{bcA}}$ & $8.41^{\mathrm{aA}}$ & $3.61^{\mathrm{cdB}}$ \\
\hline & 21 & $6.57^{\mathrm{aAB}}$ & $8.29^{\mathrm{abA}}$ & $4.16^{\mathrm{bcA}}$ \\
\hline \multirow[t]{4}{*}{$\mathrm{C2}$} & Zero & $5.19^{\mathrm{abcB}}$ & $5.99^{\mathrm{bD}}$ & $3.41^{\mathrm{aA}}$ \\
\hline & 7 & $6.60^{\mathrm{abA}}$ & $6.49^{\mathrm{cC}}$ & $3.67^{\mathrm{bA}}$ \\
\hline & 14 & $6.76^{\mathrm{bA}}$ & $7.59^{\mathrm{bcB}}$ & $3.81^{\mathrm{cA}}$ \\
\hline & 21 & $6.01^{\mathrm{aAB}}$ & $8.16^{\mathrm{bA}}$ & $3.95^{\mathrm{cA}}$ \\
\hline \multirow[t]{4}{*}{ M2 } & Zero & $5.83^{\mathrm{aB}}$ & $5.32^{\mathrm{cB}}$ & $3.42^{\mathrm{aC}}$ \\
\hline & 7 & $6.69^{\mathrm{aA}}$ & $8.23^{\mathrm{aA}}$ & $3.68^{\mathrm{bB}}$ \\
\hline & 14 & $6.55^{\mathrm{bcA}}$ & $8.35^{\mathrm{a} A}$ & $4.10^{\mathrm{bA}}$ \\
\hline & 21 & $6.39^{\mathrm{aAB}}$ & $8.18^{\mathrm{bA}}$ & $4.20^{\mathrm{bA}}$ \\
\hline
\end{tabular}

Small latter $=$ (treatment effect in the same time storage $)$, Capital latter $=($ storage effect in the same treatment $)$

Con1 $=$ Treatment with $1 \%$ milk fat, $\mathbf{O 1}=$ Treatment with $1 \%$ olive oil, $\mathbf{S 1}=$ Treatment with $1 \%$ sunflower oil, $\mathbf{C 1}=$ Treatment with $1 \%$ corn oil, $\mathbf{M 1}=$ Treatment with $1 \%$ sesame oil, Con2 $=$ Treatment with $2 \%$ milk fat, $\mathbf{O 2}=$ Treatment with $2 \%$ olive oil, $\mathbf{S 2}=$ Treatment with $2 \%$ sunflower oil, $\mathbf{C 2}=$ Treatment with $2 \%$ corn oil, $\mathbf{M 2}=$ Treatment with $2 \%$ sesame oil.

\subsection{Pathogenic group of labneh Treatments During Storage}

Coliform group (data do not show): Notably, coliforms were not detected in fresh labneh and during storage period in all treatments, which indicated the good pasteurization and hygienic condition followed in its production [7].

Counts of Staph. aureus (data do not show): Staphylococcus aureus were not detected in fresh or stored labneh, this might be due to the efficient heat treatment of milk and high sanitation conditions during manufacture and storage.

\subsection{Organoleptic Properties}

The organoleptic properties of the different labneh were also investigated and the results are presented in Table (4). Organoleptic properties showed that with the increase in the percentage of unsaturated vegetable oils and fats, the total score of labneh treatments decreased, except for sesame oil. When added at ratio $2 \%$, the total score increased this may be due to the taste and flavor compounds present in sesame oil. This results agreement with Shimoda, et al. [37] and Schieberle [38] who reported that pyrazines, pyrroles, thiazoles, thiophenes and furans, which are the major volatile compounds responsible for the aroma of sesame oil may play a role in higher flavour score of labneh containing 2\% sesame oil [24]. The data is also similar Abbas, et al. [33]. Also, treatment S1 (at 21 days) was the best treatment recorded 95.7 followed by treatment $\mathrm{C} 1$ recorded 95.4 (at zero time), while the lowest 
treatment in the total score was $\mathrm{O} 2$ treatment (at 14 days) recorded 78.5 followed by $\mathrm{S} 2$ treatment recorded 79.3 . Nevertheless, Fresh labneh containing 1\% corn oil and sunflower oil were more acceptable than the control. Also, we found that fresh labneh treatments was fortified with $2 \%$ olive oil, corn oil, sunflower oil and sesame oil were more acceptable than the control. This is considered a good result, as the treatment with oils showed a sensory acceptance from the control labneh. In addition, the highest treatment in total score was $\mathrm{C} 1$ recorded 95.4 followed by S1 treatment recorded 95.3 that increased score might be due to the highest values of odor and flavor. While the lowest treatment was Con 2 recorded 81 followed by $\mathrm{O} 2$ treatment recorded 83.9. That decreased score might be due to the lowest values of odor and flavor.

It is noted, total score of labneh treatments changed in storage periods, treatment Con1 had the highest total score at the end of storage recorded 95.1. Treatment $\mathrm{O} 1$ had the highest total score at zero time recorded 93.1. Also, the total score decreases gradually until reached to the lowest value at 14 days recorded 88.8 . While the total score decreased gradually at 7 days and 14 days then increased until reached to the highest value at 21 days. On the other side, treatment M1 increased at 7 days then decreased at 14 days then increased until reached to the highest value at 21 days. In addition, the total score of treatment Con 2 increased gradually until reached to the highest value at 21 days, while the total score of treatment $\mathrm{O} 2$ increased at 7 days then decreased at 14 days until reached to the highest value at 21 days. However, the total score of treatment decreased gradually until reached to the lowest value at 21 days, while the total score of treatment $\mathrm{C} 2$ were constant but it recorded the lowest value at 14 days. While the total score of treatment M2 decreased at 7 days recorded the lowest value then increased gradually. In general, the most labneh treatments recorded the lowest value at 14 days may be due to change in the balance of fat, protein, moisture Aydinol and Ozcan [39].

In addition, there was not considerable differences were observed in the appearance of fortified labneh compared with control. As the increase of storage period under refrigerated storage conditions $\left(4^{\circ} \mathrm{C}\right)$, the values of appearance do not change. Also, it can be concluded that vegetable oils can be used to increase the shelf life of labneh for up to 21 day at $5 \pm 1^{\circ} \mathrm{C}$ with acceptable flavour and good appearance without any signs of spoilage organisms. The consumer acceptance of cheese was affected by its appearance, texture and flavour, which are affected by a combination of the microbiological, biochemical, and technological parameters of cheese [40]. Moreover, it is recommended to fortify labneh with olive oil, sunflower oil, corn oil and sesame oil for enhancing the organoleptic properties of labneh compared with the control.

Table-4. Organoleptic properties of labneh treatments during storage period

\begin{tabular}{|c|c|c|c|c|c|c|}
\hline Treatment & $\begin{array}{l}\text { Storage Period } \\
\text { (Days) }\end{array}$ & $\begin{array}{l}\text { Appearance } \\
\text { (20) }\end{array}$ & $\begin{array}{l}\text { Body and } \\
\text { texture (30) }\end{array}$ & $\begin{array}{l}\text { Odor } \\
(20)\end{array}$ & $\begin{array}{l}\text { Flavour } \\
(30)\end{array}$ & $\begin{array}{l}\text { Total score } \\
(\mathbf{1 0 0 )}\end{array}$ \\
\hline \multirow[t]{4}{*}{$\overline{C o n 1}$} & Zero & $18.9^{\mathrm{abA}}$ & $29.4^{\mathrm{aA}}$ & $19^{\mathrm{a} A}$ & $27.3^{\mathrm{abAB}}$ & $94.6^{\mathrm{aA}}$ \\
\hline & 7 & $19^{\mathbf{a} A}$ & $28.2^{\mathrm{aA}}$ & $17^{\mathrm{aA}}$ & $26.2^{\mathrm{abAB}}$ & $92.4^{\mathrm{aA}}$ \\
\hline & 14 & $19^{\mathrm{abA}}$ & $28.9^{\mathrm{abA}}$ & $17.2^{\mathrm{aA}}$ & $25.8^{\mathrm{aB}}$ & $90.9^{\mathrm{aA}}$ \\
\hline & 21 & $19.4^{\mathrm{aA}}$ & $28.9^{\mathrm{aA}}$ & $18.4^{\mathrm{abA}}$ & $28.9^{\mathrm{aA}}$ & $95.1^{\mathrm{aA}}$ \\
\hline \multirow[t]{4}{*}{01} & Zero & $19^{\mathrm{abA}}$ & $29.3^{\mathrm{aA}}$ & $18.9^{\mathrm{aA}}$ & $25.7^{\text {abcA }}$ & $93.1^{\mathrm{abA}}$ \\
\hline & 7 & $19.1^{\mathrm{aA}}$ & $28.2^{\mathrm{aA}}$ & $17.2^{\mathrm{aA}}$ & $25^{\mathrm{abA}}$ & $90.4^{\mathrm{abA}}$ \\
\hline & 14 & $18.9^{\mathrm{abA}}$ & $28.2^{\mathrm{abcA}}$ & $17^{\mathrm{aA}}$ & $24.7^{\mathrm{abA}}$ & $88.8^{\mathrm{aA}}$ \\
\hline & 21 & $19.1^{\mathrm{aA}}$ & $28.3^{\mathrm{aA}}$ & $16.7^{\mathrm{abcA}}$ & $24.8^{\mathrm{cdA}}$ & $88.9^{\mathrm{abA}}$ \\
\hline \multirow[t]{4}{*}{ S1 } & Zero & $18.9^{\mathrm{abA}}$ & $29.2^{\mathrm{aA}}$ & $19.4^{\mathrm{aA}}$ & $27.8^{\mathrm{aA}}$ & $95.3^{\mathrm{aA}}$ \\
\hline & 7 & $19.2^{\mathrm{aA}}$ & $28.4^{\mathrm{aA}}$ & $17.4^{\mathrm{aA}}$ & $27.6^{\mathrm{aA}}$ & $92.6^{\mathrm{aA}}$ \\
\hline & 14 & $18.2^{\mathrm{abcA}}$ & $26.7^{\mathrm{abcA}}$ & $17.4^{\mathrm{aA}}$ & $25.1^{\mathrm{abA}}$ & $88.5^{\mathrm{aA}}$ \\
\hline & 21 & $19.5^{\mathrm{a} A}$ & $28.9^{\mathrm{aA}}$ & $18.7^{\mathrm{aA}}$ & $28.6^{\mathrm{abA}}$ & $95.7^{\mathrm{aA}}$ \\
\hline \multirow[t]{4}{*}{ C1 } & Zero & $19.2^{\mathrm{aA}}$ & $28.7^{\mathrm{aA}}$ & $19.2^{\mathrm{aA}}$ & $28.3^{\mathrm{aA}}$ & $95.4^{\mathrm{aA}}$ \\
\hline & 7 & $18.8^{\mathrm{aA}}$ & $27.9^{\mathrm{aA}}$ & $17.9^{\mathrm{aA}}$ & $28.2^{\mathrm{aA}}$ & $92.8^{\mathrm{aA}}$ \\
\hline & 14 & $19.5^{\mathrm{aA}}$ & $29.3^{\mathrm{aA}}$ & $16.3^{\mathrm{aA}}$ & $26^{\mathrm{aA}}$ & $91.5^{\mathrm{aA}}$ \\
\hline & 21 & $19.5^{\mathrm{aA}}$ & $28.9^{\mathrm{aA}}$ & $18.4^{\mathrm{abA}}$ & $29.1^{\mathrm{a} \mathrm{A}}$ & $94^{\mathrm{aA}}$ \\
\hline \multirow[t]{4}{*}{ M1 } & Zero & $17.4^{\mathrm{abA}}$ & $27.3^{\mathrm{abA}}$ & $18.1^{\mathrm{abA}}$ & $24.6^{\mathrm{bcA}}$ & $87.2^{\mathrm{bcAB}}$ \\
\hline & 7 & $18.6^{\mathrm{aA}}$ & $27.9^{\mathrm{aA}}$ & $17.3^{\mathrm{aAB}}$ & $24.6^{\mathrm{abA}}$ & $89.4^{\mathrm{abA}}$ \\
\hline & 14 & $17.8^{\mathrm{abcA}}$ & $26.1^{\mathrm{abc} \mathrm{A}}$ & $15.6^{\mathrm{aB}}$ & $19.4^{\mathrm{bB}}$ & $78.9^{\mathrm{aB}}$ \\
\hline & 21 & $19.1^{\mathrm{aA}}$ & $29.3^{\mathrm{aA}}$ & $18.4^{\mathrm{abA}}$ & $27.8^{a b c A}$ & $94.6^{\mathrm{aA}}$ \\
\hline \multirow[t]{4}{*}{ Con2 } & Zero & $17.1^{\mathrm{bA}}$ & $26.6^{\mathrm{bA}}$ & $15.5^{\mathrm{cdA}}$ & $24.8^{\mathrm{bcA}}$ & $81^{\mathrm{dA}}$ \\
\hline & 7 & $15.5^{\mathrm{bA}}$ & $25.2^{\mathrm{aA}}$ & $18^{\mathrm{a} A}$ & $25.3^{\mathrm{abA}}$ & $83^{\mathrm{abA}}$ \\
\hline & 14 & $16^{\mathrm{cA}}$ & $24.3^{\mathrm{cA}}$ & $17.4^{\mathrm{aA}}$ & $24.7^{\mathrm{abA}}$ & $82.7^{\mathrm{aA}}$ \\
\hline & 21 & $17^{\mathrm{abA}}$ & $28.3^{\mathrm{a} A}$ & $17.4^{\mathrm{abcA}}$ & $25.2^{\mathrm{bcdA}}$ & $88.9^{\mathrm{abA}}$ \\
\hline \multirow[t]{4}{*}{$\mathbf{O 2}$} & Zero & $17.5^{\mathrm{abA}}$ & $27.7^{\mathrm{abA}}$ & $14.3^{\mathrm{dA}}$ & $24.4^{\mathrm{cAB}}$ & $83.9^{\mathrm{cd} A}$ \\
\hline & 7 & $17.3^{\mathrm{abA}}$ & $26.9^{\mathrm{aA}}$ & $16.6^{\mathrm{aA}}$ & $25.6^{\mathrm{abA}}$ & $86.4^{\mathrm{abA}}$ \\
\hline & 14 & $17.1^{\mathrm{abcA}}$ & $25.3^{\mathrm{abcA}}$ & $16.1^{\mathrm{aA}}$ & $19.9^{\mathrm{abB}}$ & $78.5^{\mathrm{aA}}$ \\
\hline & 21 & $18.8^{\mathrm{aA}}$ & $28.2^{\mathrm{aA}}$ & $15.4^{\mathrm{cA}}$ & $24.8^{\mathrm{cdA}}$ & $87.2^{\mathrm{abA}}$ \\
\hline \multirow[t]{4}{*}{ S2 } & Zero & $18.6^{\mathrm{abA}}$ & $27.7^{\mathrm{abA}}$ & $16.5^{\mathrm{bcA}}$ & $26.8^{\mathrm{abcA}}$ & $89.6^{\mathrm{abcA}}$ \\
\hline & 7 & $18.1^{\mathrm{aA}}$ & $27.2^{\mathrm{Aa}}$ & $16.6^{\mathrm{aA}}$ & $24.5^{\mathrm{abAB}}$ & $86.4^{\mathrm{abA}}$ \\
\hline & 14 & $16.5^{\mathrm{bcA}}$ & $25.9^{\mathrm{abcA}}$ & $16.2^{\mathrm{a} A}$ & $20.8^{\mathrm{abB}}$ & $79.3^{\mathrm{aA}}$ \\
\hline & 21 & $17.2^{\mathrm{abA}}$ & $26^{\mathrm{bA}}$ & $15.8^{\mathrm{bcA}}$ & $23.4^{\mathrm{dAB}}$ & $80.9^{\mathrm{bA}}$ \\
\hline
\end{tabular}




\begin{tabular}{l|l|l|l|l|l|l}
\hline \multirow{3}{*}{ C2 } & Zero & $18.8^{\mathrm{abA}}$ & $27.8^{\mathrm{abA}}$ & $17.8^{\mathrm{abA}}$ & $27.3^{\mathrm{abA}}$ & $90.7^{\mathrm{abA}}$ \\
\cline { 2 - 7 } & $\mathbf{7}$ & $17.9^{\mathrm{aA}}$ & $26.6^{\mathrm{aAB}}$ & $18.2^{\mathrm{aA}}$ & $27.1^{\mathrm{aA}}$ & $90.8^{\mathrm{abA}}$ \\
\cline { 2 - 7 } & $\mathbf{1 4}$ & $18^{\mathrm{abcA}}$ & $24.6^{\mathrm{bcB}}$ & $16.8^{\mathrm{aA}}$ & $24.6^{\mathrm{abA}}$ & $83.6^{\mathrm{aA}}$ \\
\cline { 2 - 7 } & $\mathbf{2 1}$ & $15.6^{\mathrm{bA}}$ & $27.7^{\mathrm{abA}}$ & $17.3^{\mathrm{abcA}}$ & $26.6^{\mathrm{abcdA}}$ & $90^{\mathrm{aA}}$ \\
\cline { 2 - 7 } & Zero & $18.6^{\mathrm{abA}}$ & $27.7^{\mathrm{abA}}$ & $17.5^{\mathrm{abA}}$ & $26.6^{\mathrm{abcAB}}$ & $90.4^{\mathrm{abA}}$ \\
\cline { 2 - 7 } & $\mathbf{7}$ & $17.7^{\mathrm{aA}}$ & $26.4^{\mathrm{aA}}$ & $18.3^{\mathrm{aA}}$ & $22.5^{\mathrm{bB}}$ & $80.9^{\mathrm{bA}}$ \\
\cline { 2 - 7 } & $\mathbf{1 4}$ & $18.2^{\mathrm{abc}}$ & $25.8^{\mathrm{abcA}}$ & $17.9^{\mathrm{aA}}$ & $24.1^{\mathrm{abAB}}$ & $86^{\mathrm{aA}}$ \\
\cline { 2 - 7 } & $\mathbf{2 1}$ & $18.6^{\mathrm{aA}}$ & $27.1^{\mathrm{abA}}$ & $18^{\mathrm{abA}}$ & $27.4^{\mathrm{abcA}}$ & $90.1^{\mathrm{aA}}$ \\
\hline
\end{tabular}

Small latter $=$ (treatment effect in the same time storage $)$, Capital latter $=$ (storage effect in the same treatment $)$

Con1 $=$ Treatment with $1 \%$ milk fat, $\mathbf{O 1}=$ Treatment with $1 \%$ olive oil, $\mathbf{S 1}=$ Treatment with $1 \%$ sunflower oil, $\mathbf{C 1}=$ Treatment with $1 \%$ corn oil, $\mathbf{M 1}=$ Treatment with $1 \%$ sesame oil, Con2 = Treatment with $2 \%$ milk fat, $\mathbf{O 2}=$ Treatment with $2 \%$ olive oil, $\mathbf{S 2}$ $=$ Treatment with $2 \%$ sunflower oil, $\mathbf{C 2}=$ Treatment with $2 \%$ corn oil, $\mathbf{M} 2=$ Treatment with $2 \%$ sesame oil.

\subsection{Rheological Properties of 1-2\% Fresh labneh Treatments with Vegetable Oils}

Rheological properties of fresh Labneh samples are shown in Table (5). Fracture (the Force with which food fractures) $[15,41], \mathrm{C} 1$ recorded the highest value $7.5(\mathrm{~N})$ while Con1, S2 and C2 treatments recorded the lowest value $0.6(\mathrm{~N})$. Hardness (the force required to compress a sample between the molars) [15, 41]. Con1 recorded the highest hardness value $8.9(\mathrm{~N})$, while the lowest treatment was $\mathrm{S} 1$ recorded $4.3(\mathrm{~N})$. It is noticed that the hardness is higher in control treatments than labneh fortified with vegetable oils. Data showed that hardness values were being the highest in the control treatment, decreased gradually by increase the add ratio from vegetable oils may be due to the increase of PUSF content with increase the rate of vegetable oils. Also, control treatments the highest values because it contains higher SFA [42]. These observations may be related to the ratio of TS by Saad, et al. [27]. Also, These results agreement with El-Sayed, et al. [34]. Adhesiveness (the tendency of labneh material to adhere with other material or surface [1]. Data in Table (5) showed that the (O1) had the highest adhesiveness value recorded $6.608(\mathrm{mj})$ and Con2 had lowest adhesiveness value $2.022(\mathrm{mj})$. These results differ from Habib, et al. [43]. Cohesiveness (the strength of internal bonds making up the body of the product [15, 41]. Data in Table (5) showed that the $\mathrm{O} 2$ had the highest cohesiveness Value recorded 0.51 (Ratio), while Con 1 had low cohesiveness value 0.31 (Ratio). It is noticed that the cohesiveness is lower in control treatments than labneh fortified with vegetable oils. While the increase in the percentage of addition of vegetable oil, the cohesiveness values increase, except for labneh fortified with sesame oil, this value decreased. These results agreement with Habib, et al. [43] and El-Sayed, et al. [34]. Springiness: The rate at which a deformed material returns to its original shape on removal of the deforming force $[15,41]$. Data in Tables (5) showed that the M1 had the highest springiness value 9.79 (mm), while O2 had lowest springiness value 3.38 (mm) these results differ from Habib, et al. [43] and El-Sayed, et al. [34]. Gumminess Force needed to disintegrate a semisolid food to a state ready for swallowing obtained from product of hardness and cohesiveness $(\mathrm{N})[15,41]$. The data represented in Table (5) showed that the M1 had the highest gumminess value recorded $4.3(\mathrm{~N})$, while $\mathrm{S} 2$ had low gumminess value recorded $1.9(\mathrm{~N})$. It is noticed that gumminess values decreased with increase vegetable oils ratio except $\mathrm{O} 2$ treatment recorded same value. These results agreement with El-Sayed, et al. [34] who reported that gumminess decreased with increase oil ratio, gumminess was decreased when protein content decreased, and fat (Moringa oleifera oil) increased. Chewiness work needed to masticate a solid food to a state ready for swallowing Obtained from Product of hardness, cohesiveness, and springiness [15, 41]. The data represented in and showed that the M1 had the highest chewiness value recorded 42.55 (mj), while S2 had low Gumminess value recorded 8.57 (mj) It is noticed that chewiness values decreased with increase vegetable oils ratio. These results agreement with El-Sayed, et al. [34] who reported that chewiness decreased with increase oil ratio. Also, chewiness affected by TS.

Table-5. Rheological properties of 1-2\% fresh labneh treatments

\begin{tabular}{l|l|l|l|l|l|l|l}
\hline Treatments & Fra $(\mathbf{N})$ & Har $(\mathbf{N})$ & Adh $(\mathbf{m j})$ & Coh $($ Ratio $)$ & Spr $(\mathbf{m m})$ & Gum $(\mathbf{N})$ & Che $(\mathbf{m j})$ \\
\hline Con1 & 0.6 & 8.9 & 4.001 & 0.31 & 5.20 & 2.8 & 14.45 \\
\hline O1 & 2.8 & 6.5 & 3.777 & 0.445 & 5.56 & 2.9 & 15.89 \\
\hline S1 & 5.1 & 6.4 & 5.716 & 0.44 & 5.47 & 2.8 & 15.48 \\
\hline C1 & 7.5 & 7.6 & 2.801 & 0.38 & 5.03 & 2.9 & 14.44 \\
\hline M1 & 1.6 & 7.1 & 2.459 & 0.61 & 9.79 & 4.3 & 42.55 \\
\hline Con2 & 7.00 & 7.1 & 2.022 & 0.39 & 5.08 & 2.8 & 14.07 \\
\hline O2 & 5.3 & 5.6 & 6.608 & 0.51 & 3.38 & 2.9 & 9.66 \\
\hline S2 & 0.6 & 4.3 & 3.985 & 0.45 & 4.41 & 1.9 & 8.57 \\
\hline C2 & 0.6 & 6.7 & 6.43 & 0.39 & 5.39 & 2.6 & 14.02 \\
\hline M2 & 6.4 & 6.5 & 5.467 & 0.49 & 4.82 & 3.2 & 15.44 \\
\hline
\end{tabular}

Con1 = Treatment with $1 \%$ milk fat, $\mathbf{O 1}=$ Treatment with $1 \%$ olive oil, $\mathbf{S 1}=$ Treatment with $1 \%$ sunflower oil, $\mathbf{C 1}=$ Treatment with $1 \%$ corn oil, $\mathbf{M 1}=$ Treatment with $1 \%$ sesame oil. Con2 $=$ Treatment with $2 \%$ milk fat, $\mathbf{O 2}=$ Treatment with $2 \%$ olive oil, $\mathbf{S 2}=$ Treatment with $2 \%$ sunflower oil, $\mathbf{C 2}=$ Treatment with $2 \%$ corn oil, $\mathbf{M 2}=$ Treatment with $2 \%$ sesame oil.

Fra = Fracture Har = Hardness $;$ Adh = Adhesiveness $;$ Coh = Cohesiveness $;$ Spr = Springiness $;$ Gum = Gumminess and Che = Chewiness

Effect adding 1-2\% vegetable oils on time of coagulation of fresh labneh treatments and pH value: The effect of adding olive, corn, sunflower and sesame oils on coagulation time and $\mathrm{pH}$ value after complete coagulation was shown in Table (6). Coagulation time of S1 treatment was 320 minutes followed by O1 treatment was 270 
minutes while $\mathrm{C} 1$ and $\mathrm{C} 2$ treatments recorded shortest coagulation time was 202 minutes. Data in Table (6) presented $\mathrm{pH}$ value after complete coagulation we found that $\mathrm{M} 2$ treatment recorded the highest $\mathrm{pH}$ value was 5.22 followed by $\mathrm{C} 2$ treatment recorded 5.05. While the lowest $\mathrm{pH}$ value was treatment $\mathrm{M} 1$ recorded 3.98 followed by $\mathrm{O} 1$ treatment 0078 recorded 4.44 .

Curd tension of fresh labneh treatments: Data in Table (6) elucidated the changes in curd tension of labneh fortified with olive, sunflower, corn, and sesame oils at ratios of $1 \%$ and $2 \%$. Curd tension was measured after the complete end of the coagulation time at $43^{\circ} \mathrm{C}$ in the incubator. Curd tension was measured as the weight of the needed mass to removing the fork out of the fresh coagulated curd. The highest value was observed in S2 treatment recorded $49.61 \mathrm{gm}$, while $\mathrm{C} 2$ treatment recorded $36.96 \mathrm{gm}$.

Curd syneresis of fresh labneh treatments: Curd syneresis was performed by weighting $15 \mathrm{gm}$ of fresh coagulated curd from each treatment, then it was left for whey draining over a metal net for various intervals $(15,30$ and $60 \mathrm{~min})$. From data in Table (6) results indicated that treatment M2 had the highest curd syneresis (5.5ml), followed by treatment M1 $(4.6 \mathrm{ml})$, while Con1 treatment had the lowest curd syneresis $(2.9 \mathrm{ml})$, followed by treatment Con2 $(3.1 \mathrm{ml})$. These results agreement with Farmani, et al. [44]. Viscosity and melting point of vegetable oils, which can result in a looser texture. The greater the oil's viscosity, the greater the protein's capacity to immobilize water and increase the strength of the gel network, resulting in whey reduction [31].

Effect adding 1-2\% vegetable oils on yield of labneh treatments: From Table (6) we found that the highest value of yield of labneh treatments was S2 recorded 32.9 followed by $\mathrm{C} 2$ and $\mathrm{O} 2$ recorded 29.8 and 29.8. Also, the lowest value of yield of labneh treatments was $\mathrm{C} 1$ recorded 18.4 followed by M1 recorded 21.7. Notably all samples gave yield more than the control treatments, with the exception $\mathrm{C} 1$ and $\mathrm{M} 1$. In addition. All treatments fortified with $2 \%$ vegetable oils gave yield more than that fortified with $1 \%$ vegetable oils this is likely due to the increased fat content.

Table-6. Effect adding 1-2\% vegetable oils on time of coagulation, Curd tension, Curd Syneresis and Yields of fresh labneh treatments

\begin{tabular}{l|l|l|l|l|l|l|l}
\hline Treatments & Time of coagulation & \multirow{2}{*}{$\begin{array}{l}\text { Curd } \\
\text { tension }\end{array}$} & \multicolumn{2}{l|}{ Curd Syneresis $(\mathbf{m l})$} & Yield \\
\cline { 5 - 8 } & & $\mathbf{1 5}$ minutes & $\mathbf{3 0}$ minutes & $\mathbf{6 0}$ minutes & Total & \\
\hline Con1 & $(200) / 4.51$ & 42.30 & 2.5 & 0.3 & 0.1 & 2.9 & 22.2 \\
\hline Con2 & $(207) / 4.94$ & 41.57 & 2.9 & 0.1 & 0.1 & 3.1 & 22.4 \\
\hline O1 & $(270) / 4.44$ & 45.37 & 3.3 & 1.1 & 0.2 & 4.6 & 23.8 \\
\hline O2 & $(237) / 4.79$ & 44.85 & 3 & 0.9 & 0.1 & 4 & 29.8 \\
\hline S1 & $(320) / 4.45$ & 40.24 & 3.5 & 0.1 & 0.1 & 3.7 & 22.5 \\
\hline S2 & $(218) / 4.96$ & 49.61 & 4 & 0.2 & 0.1 & 4.3 & 32.9 \\
\hline C1 & $(202) / 4.61$ & 42.31 & 3.2 & 1.1 & 0.2 & 4.5 & 18.4 \\
\hline C2 & $(202) / 5.05$ & 36.966 & 3.9 & 0.2 & 0.1 & 4.2 & 29.8 \\
\hline M1 & $(235) / 3.98$ & 41.026 & 3.2 & 0.9 & 0.2 & 4.3 & 21.7 \\
\hline M2 & $(207) / 5.22$ & 42.303 & 4.1 & 1.3 & 0.1 & 5.5 & 23.5 \\
\hline Con1
\end{tabular}

Con1 = Treatment with $1 \%$ milk fat, $\mathbf{O 1}=$ Treatment with $1 \%$ olive oil, S1 $=$ Treatment with $1 \%$ sunflower oil, $\mathbf{C 1}=$ Treatment with $1 \%$ corn oil, M1 = Treatment with $1 \%$ sesame oil, $\mathbf{C o n} \mathbf{2}=$ Treatment with $2 \%$ milk fat, $\mathbf{O 2}=$ Treatment with $2 \%$ olive oil, $\mathbf{S 2}=$ Treatment with $2 \%$ sunflower oil, $\mathbf{C 2}=$ Treatment with $2 \%$ corn oil, $\mathbf{M 2}=$ Treatment with $2 \%$ sesame oil

\section{Conclusion}

Labneh produced with 1-2\% virgin olive, corn, sunflower and sesame oils can be considered as a new product with functional properties and good acceptability. It is concluded that is the best treatment that fortified with $1 \%$ sunflower oil higher than control.

\section{References}

[1] Shamsia, S. M. and El-Ghannam, M. S., 2012. "Manufacture of labneh from cow's milk using ultrafiltration retentate with or without addition of permeate concentrate." Journal of Animal Production Advances, vol. 2 , pp. 166-173.

[2] Ramos, T. M., Gajo, A. A., Pinto, S. M., Abreu, L. R., and Pinheiro, A. C., 2009. "Perfil de textura de labneh (iogurte grego)." Revista do Instituto de Laticínios Cândido Tostes, vol. 64, pp. 8-12.

[3] Fasina, O. O., Hallman, C. H. M., and Clementsa, C., 2006. "Predicting temperature-dependence viscosity of vegetable oils from fatty acid composition." JAOCS, vol. 83, pp. 899-903.

[4] Dzisiak, D., 2004. "New oils reduced saturated and Trans fats in processed foods." Cereal Foods World, vol. 49, pp. 331-333.

[5] Sowmya, M., Jeyarani, T., Jyotsna, R., and Indrani, D., 2009. "Effect of replacement of fat with sesame oil and additives on rheological, microstructural, quality characteristics and fatty acid profile of cakes." Food Hydrocolloids, vol. 23, pp. 1827-1836. Available: http://dx.doi.org/10.1016/j.foodhyd.2009.02.008

[6] Ocakoglu, D., Tokatli, F., Ozen, B., and Korel, F., 2009. "Distribution of simple phenols, phenolic acids and flavonoids in Turkish monovarietal extra virgin olive oils for two harvest years." Food Chem., vol. 113, pp. 401-410.

[7] Abou, A. I. A. A. and Gamal, E. D. A. A., 2011. "Improvement of the properties of Goat's milk Labneh using some aromatic and vegetable oil." International Journal of Dairy Sci., vol. 6, pp. 112-123. 
[8] Thabet, H. M., Nogaim, Q. A., Qasha, A. S., Abdoalaziz, O., and lnsheme, N., 2014. "Evaluation of the effects of some plant derived essential oils on shelf-life extension of Labneh." Merit Res. J. Food Sci. Technol., vol. 2, pp. 8-14.

[9] American Public Health Association APHA, 1998. Standard Methods for the Examination of water and wastewater. 20th ed. New York: APHA, Inc.

[10] De Man, J. C., Rogosa, D., and Sharpe, M. E., 1960. "A medium for the cultivation of lactobacilli." Journal of Applied Bacteriology, vol. 23, pp. 130-135.

[11] Marshall, T. R., 1992. Standard methods for the examination of dairy Products. Washington, DC: American Public Health Association.

[12] Association of official Agriculture Chemists AOAC, 2012. Official methods of official Analysis chemists. 19th Ed. William Hornitz, (Ed) pub Association of official Agric. Washington, DC, USA: Chemists.

[13] Chandrasekhara, M. R., Bhagawan, R. K., Swaminathan, M., and Subrahmanyan, V., 1957. "The use of mammalian milk and processed milk foods in the feeding of infants." Indian Journal of Child Health, vol. 6, pp. 701-710.

[14] Lawrenece, R. C., 1989. The use of ultrafiltration technology in cheese making. Brussels, Bulletin of Belgium: Bulletin 240, Int. Dairy Fed. pp. 2-15.

[15] Szczesniak, A. S., Brandt, M. A., and Friedman, H. H., 1963. "Development of standard rating scales for mechanical parameters of texture and correlation between the objective and the sensory methods of texture evaluation." Journal of Food Science, vol. 28, pp. 397-403.

[16] Keating, K. R. and White, C. H., 1990. "Effect of alternative sweeteners in plain and fruit-flavored yogurts." J. Dairy Sci., vol. 73, pp. 54-62.

[17] SAS, 1991. SAS User's guide: statistics. SAS Inst, Inc, Cary, NC.

[18] Duncan, D. B., 1955. "Multiple range and multiple f-test." Biometrics, vol. 11, pp. 1-42.

[19] Abbas, F. and Osman, M., 1998. "Properties of Labneh like products manufactured using acid and acid rennet coagulation." Annal. Agric. Sci. Moshtohor., vol. 36, pp. 401-411.

[20] Guler, Z., 2007. "Changes in salted yogurt during storage." International Journal of Food Science and Technology, vol. 42, pp. 235-245.

[21] Senel, E., Atamer, M., Gursoy, A., and Oztekin, F. S., 2011. "Changes in some properties of strained (Suzme) goat's yogurt during storage." Small Rumin. Res., vol. 99, pp. 171-177.

[22] Ersoz, E., Kinik, O., Yerlikaya, O., and Acu, M., 2011. "Effect of phenolic compounds on characteristics of strained yoghurts produced from sheep milk." Afr. J. Agric. Res., vol. 6, pp. 5351-5359.

[23] Zaky, W. M., Kassem, J. M., Abbas, H. M., and Mohamed, S. H. S., 2013. "Evaluation of salt-free labneh quality prepared using dill and caraway essential oils." Life Sci. J., vol. 10, pp. 3379-3386.

[24] Elama, C., Alayoubi, M., Jazzar, M., and Fuad, A. R., 2019. "Effect of different essential oils on the shelf life of concentrated yogurt." Annual Research and Review in Biology, vol. 30, pp. 1-9.

[25] Mutlag, A. and Hassan, E., 2008. "Improvement of the quality and shelf life of Concentrated yoghurt (labneh) by the addition of some essential oils." African Journal of Microbiology Research, vol. 2, pp. 156161.

[26] Mehaia, M. A. and El Khadragy, S. M., 1999. "Compositional, characteristics and sensory evaluation of labneh made from goat's milk." Milchwissenschaft, vol. 54, pp. 567-569.

[27] Saad, S. A., Salama, H. H., and El-Sayed, H. S., 2015. "Manufacture of functional Labneh using UFretentate and artichoke puree." Int. J. Dairy Sci., vol. 10, pp. 186-197.

[28] Abou Jaoude, D., Olabi, A., Najm, N. E. O., Malek, A., Saadeh, C., Baydoun, E., and Toufeili, I., 2010. "Chemical composition, mineral content, and cholesterol levels of some regular and reduced-fat white brined cheeses and strained yogurt (Labneh)." Dairy Science and Technology, vol. 90, pp. 699-706.

[29] Ghoneem, G. A., Ismail, M. M., Boraey, N. A., Tabekha, M. M., and Elashrey, H. F., 2017. "Effect of blending soy milk with cow milk on some properties of bio-labneh." International Journal of Nutrition and Food Science, vol. 2, pp. 1-12.

[30] Ismail, A. M., Harby, S., and Salem, A. S., 2006. "Production of flavored labneh with extended shelf life." Egyptian J. Dairy Sci., vol. 34, pp. 59-68.

[31] Tamime, A. Y. and Robinson, R. K., 2007. Tamime and robinson's yoghurt science and technology. 3rd ed. Boca Raton: CRC Press. pp. 13-161.

[32] Ayana, I. A. A. A. and El-Shabraw, H. M., 2014. "Improvement of milk composition and properties of labneh using oil seeds as supplement for lactating zaraibi goat rations." Current Research in Dairy Sciences, vol. 7, pp. 1-17. Available: https://doi.org/10.3923/crds.2015.1.17

[33] Abbas, H. M., M., H. F. A., kassem, J. M., Ramsy, N. M., El-kaluobi, M. H., and El-okaby, M. F., 2015. "Preparation of cheese yoghurt using extracted high virgin Olive oil." International Journal of Dairy Science, vol. 10, pp. 288-296.

[34] El-Sayed, S. M., El-Sayed, H. S., Salama, H. H., and El-Nor, S. A., 2017. "Improving the nutritional value and extending shelf life of labneh by adding Moringa oleifera oil." Int. J. Dairy Sci., vol. 12, pp. 81-92.

[35] Nazzaro, F., Fratianni, F., Cozzolino, R., Martignetti, A., Malorni, L., De Feo, V., and d'Acierno, A., 2019. "Antibacterial activity of three extra virgin olive oils of the campania region, southern italy, related to their polyphenol content and composition." Microorganisms, vol. 7, p. 321. 
[36] Al-Kadamany, E., Toufeili, I., Khattar, M., Abou-Jawdeh, Y., Harakeh, S., and Haddad, T., 2002. "Determination of shelf life of concentrated yogurt (Labneh) produced by in-bag straining of set yogurt using hazard analysis." Journal of Dairy Science, vol. 85, pp. 1023-1030.

[37] Shimoda, M., Shiratsuchi, H., Nakada, Y., Wu, Y., and Osajima, Y., 1996. "Identification and sensory characterization of volatile flavor compounds in sesame seed oil." Journal of Agricultural and Food Chemistry, vol. 44, pp. 3909-3912.

[38] Schieberle, P., 1996. "Odour-active compounds in sesame moderately roasted." Food Chemistry, vol. 55, pp. 145-152.

[39] Aydinol, P. and Ozcan, T., 2018. "Production of reduced-fat Labneh cheese with inulin and $\beta$-glucan fibrebased fat replacer." International Journal of Dairy Technology, vol. 71, pp. 362-371.

[40] Adhikari, K., Mustapha, A., and Gruw, I. U., 2003. "Survival and metabolic activity of microencapsulated Bifidobacterium longum in stirred yogurt." Journal of Food Science, vol. 68, pp. 275-280.

[41] Bourne, M. C., 1978. "Texture profile analysis." Food Technol, vol. 32, pp. 62-72.

[42] Barrantes, E., Tamime, A. Y., Sword, A. M., Mui, D. D., and Kalk, M., 1996. "The manufacture of set-type natural yoghurt containing different oils- 2. Rheological properties and microstructure." International Dairy Journal, vol. 6, pp. 827-837.

[43] Habib, E., Shamsia, S., Awad, S., and Ziena, H., 2017. "Physicochemical and sensory properties of labneh fortified with salvia officinalis." Alexandria Science Exchange Journal, vol. 38, pp. 761-769.

[44] Farmani, J., Edalatkhah, M., Motamedzadegan, A., and Mardani, M., 2016. "Production of set yoghurt analogue through replacement of milk fat with canola and sesame oil." International Journal of Dairy Technology, vol. 69, pp. 433-440. 